\title{
3. WNIOSKI
}

1. Analiza literacka wykazała, że Księga Jozuego powstawała etapami. Być może, że pierwszy etap (zbieranie dokumentów o podboju i podziale zdobytego kraju) miał miejsce w okresie monarchii (Dawid - Salomon).

2. Księga Jozuego ma ślady deuteronomistycznej redakcji i myśli w niej zawarte wskazują na okres reformy religijnej, a więc czasy Ezechiasza i Jozjasza.

3. Wprowadzenie w niektóre opowiadania symboli obecności Jahwe (Namiot Spotkania, Arka), wprowadzanie wzmianki o Babilonii (Joz 24, 2n), o herem, zamieszczanie obcych narodów - odseparowanie się od nich, wskazuje na czas niewoli, a więc byłaby to druga redakcja w czasach niewoli babilońskiej.

Wojnicz

KS. STANISEAW GACEK

\section{Ks. Roman Krawczyk}

\section{KOBIETA W ŚWIETLE PRZEKAZOW BIBLIJNYCH}

Kobieta we współczesnym życiu odgrywa taką samą rolę, jak mężczyzna. Warto więc zając się tym zagadnieniem w aspekcie biblijnym. Innymi słowy: jaki jest stosunek ST do kobiety? Nie jest oczywiście łatwo przedstawić ten stosunek w sposób jednoznaczny.

Artykuł ten ogranicza się jedynie do przekazów zawartych w $\mathrm{Rdz}$ 1-3 i w starotestamentalnych księgach mądrościowych. W oparciu o powyższe Księgi pragnę dać zarys syntetycznego ujęcia nauki ST o kobiecie w aspekcie teologicznym.

\section{NAUKA O KOBIECIE \\ W TRADYCJI KAPŁAŃSKIEJ I JAHWISTYCZNEJ}

Oba opisy stworzenia w Księdze Rodzaju wyrażają prawdę, że ludzkość od początków swego istnienia została zróżnicowana pod względem płci. Odmienność płciowa ludzi została ustanowiona przez samego Boga. Z opisu reprezentującego tradycję kapłańską ( $\mathrm{Rdz} 1$, 26-31) wynika, że kobieta jest w takim samym stopniu człowiekiem, co mężczyzna i jak on została stworzona na obraz Boży ${ }^{1}$. „A wreszcie

$1 \mathrm{Na}$ temat tej idei zob.: M. Filipiak, Biblia o człowieku. Zarys antropologii biblijnej Starego Testamentu, Lublin 1979, s. 79-87; A. B o- 
rzekł Bóg: uczyńmy ludzi na nasz obraz, podobnych do nas... I stworzył Bóg ludzi na swój obraz, na obraz Boga stworzył ich: stworzył mężczyznę i kobietę" ( $\mathrm{Rdz} 1,26-27)$. Z tego fundamentalnego stwierdzenia wynika jasno, że kobieta i mężczyzna, w porządku godności, są takim samym człowiekiem: razem są obrazem Bożym, razem przedmiotem błogosławieństwa, razem przedmiotem Bożej oceny ${ }^{2}$. Bóg jest źródłem podziału ludzi na dwie płci, przy czym żadna z nich nie otrzymała prawa dominacji nad drugą. Obydwoje: kobieta i mężczyzna są równi w swej ludzkiej naturze. Żadna z obu płci nie może przekazywać życia sama, każda $z$ nich jest zdana na drugą, co w zasadniczy sposób podkreśla Księga Rodzaju. W opowiadaniu tym nie dostrzega się najmniejszej nawet różnicy w dostojeństwie między obu płciami. Wynika to $\mathrm{z}$ samego tekstu, w którym autor biblijny nie używa rzeczowników: „mężczyzna" i „kobieta”, gdyż te mogłyby sugerować odrębność ich osobowości i indywidualności, lecz form przymiotnikowych: „męski” (hebr. zakar) i „niewieści” (hebr. neqebâ). Użycie tych przymiotników sugeruje więc, że w ten sposób autor $\mathrm{z}$ tradycji kapłańskiej chciał podkreślić jedynie różnice płci ${ }^{3}$.

Te same myśli, chociaż wyrażone za pomocą odmiennych środków wyrazu, przynosi opowiadanie jahwistyczne (Rdz 2, 18-25). Informuje ono, że Bóg "uformował" kobietę z cząstki ciała mężczyzny. Na oznaczenie tej cząstki Rdz 2, 21 używa słowa sélá (LXX: pleura, NVg: costa), które oznacza ,żebro”, „kość” lub, „życie”. Wzięcie z organizmu mężczyzny cząstki ciała, kości lub żebra i "zbudowanie" z niej ko oiety - wyraża myśl, iż kobieta ma taką samą naturę, jaką posiada mężczyzna. Rzeczy mają dla człowieka Wschodu na ogól głębsze znaczenie; są one "danymi przez naturę symbolami" 4

Słusznie zwraca uwagę $H$. Renckens ${ }^{5}$, że przedstawienie fizycznego czy biologicznego sposobu powstania niewiasty nie leży wcale $\mathrm{w}$ intencji autora, trzymając się jedynie tego opisu, możemy stwierdzić, że autor biblijny nie zamierza pouczać, „w jaki sposób" Bóg stworzył niewiastę, lecz jako ,jaką" istotę ją stworzył. Innymi słowy: wziąść coś z „życia" mężczyzny i użyć jej do stworzenia kobiety - to powołać do istnienia istotę równą mężczyźnie. Wg $\mathrm{Rdz} 2$, 23a Adam mówi o stworzonej kobiecie: „Ta dopiero jest kością z moich kości

nora, Czlowiek obrazem Boga $w$ Starym Testamencie, "Communio" 2 (1982), nr 2, s. 3-15; J. Chmiel, Czlowiek obrazem Boga, "Znak" 274 (1977) 363-370; O. Loretz, Die Gottebenbildlichkeit des Menschen, München 1967.

2 por. D. Merli, La creazione e la dignita della donna, BibOr 12 (1970 97-103). Por. także: F. Festorazzi, La donna e la complementarietà dei sessi nel matrimonio secondo la Bibbia, w: Evangelizzazione e matrimonio (dir. S. Cipriani), Napoli 1975, s. 214-225.

3 Por. A. A dinolfi, Il femminismo della Bibbia, Romae 1981, s. $39-40$.

${ }_{4}$ T. B o mann, Das hebräische Denken im Vergleich mit dem griechischen, Göttingen 19j4, (wyd. 2), s. 75).

5 Urgeschichte und Heilsgeschichte, Mainz 1961, (wyd. 2), s. 204. 
i ciałem z mego ciała" ${ }^{6}$. Wyrażenie to oznacza bliskie pokrewieństwo (por. Rdz 29, 14; 27, 27; 2 Sm 5, 1), w ustach natomiast Adama tożsamość natury. Identyczność kobiety co do natury z mężczyzną podkreśla również autor jahwistyczny w następnym wierszu (Rdz 2, 23b) przez fakt nazwania kobiety terminem 'îššah, „mężowa”, ponieważ została wzięta $z$ „męża” - 'îs. Kobieta więc ma tę samą naturę, co mężczyzna, jest takim samym jak on człowiekiem ${ }^{7}$.

$\mathrm{Na}$ pewną rozbieżność, jakby się wydawało, wskazuje fakt, że celem stworzenia kobiety było danie odpowiedniej „pomocy" mężczyźnie: „Nie jest dobrze, żeby mężczyzna był sam, uczynię mu zatem odpowiednią dla niego pomoc" ( $\mathrm{Rdz} 2,18)$. Użyty tutaj termin „pomoc” (hebr. ézer) nie oznacza jednak podporządkowania kobiety mężczyźnie. Stary Testament określa słowem tym często Boga jak. pomoc dla swego ludu (por. Wj 18, 4; Pwt 33, 7; Ps 27, 9; 33, 20; 146, 5) ${ }^{8}$. Kobieta nie jest więc ,pomocą" dla mężczyzny jako siła robocza, czy też narzędzie zaspokojenia popędu seksualnego lub też rodzenia potomstwa. Jedno dla drugiego stanowi pomoc w sensie egzystencjalnym - $\mathrm{w}$ osiąganiu pełni człowieczeństwa ${ }^{9}$. Bóg przeznaczył człowiekowi całego drugiego człowieka, a nie tylko funkcję człowieka. Tak rozumiana wzajemna „pomoc” kobiety i mężczyzny to warunek spełnienia bytowej pełni człowieka. „Dlatego opuszcza człowiek swego ojca i matkę $\mathrm{i}$ łączy się $\mathrm{z}$ żoną swoją, tak, że oboje stają się jednym ciałem" (Rdz 2, 24). Myśl autora biblijnego jest następująca: mężczyzna i kobieta dążą do połączenia się (hebr. dábaq) ze sobą w miłości, do stania się ,jednym ciałem" 10. Dzieje się tak z woli samego Boga, który tak właśnie ukształtował mężczyznę i kobietę.

Relacja o upadku ( $\mathrm{Rdz} 3)^{11}$ stała się dla autora biblijnego jeszcze jedną okazją do podkreślenia równości między mężczyzną i kobietą. Oboje w równym stopniu byli świadomi, wolni i odpowiedzialni za swój los, oboje w równym stopniu popełnili grzech i zostali skazani na cierpienia, aczkolwiek każde $\mathrm{z}$ nich $\mathrm{w}$ innym aspekcie dostosowanym do ich natury. Grzech był jednorodnym aktem ich obojga. Kolejność popełnienia grzechu (Ewa pierwsza spożyła owoc) nie wskazuje ani na to, że kobieta miała większy udział w grzechu, ani że

6 Por. W. Reiser, Die Verwandtschaftsformel in Genesis 2,23, ThZ 16 (1960) $1-4$.

7 E. Ehrlich, Biblia o kobiecie, RBL 6 (1975) 245-252; por. także: J. P a ściak, Kobieta w Starym Testamencie, WDr 8 (1980), nr 5, s. 47-55; E. B. Jegier, Biblijny ideat kobiety, "Życie katolickie” 3 (1984); nr 5, s. $98-104$.

8 Zob. U. Bergmann, helfen, THAT, II, s. 256-259.

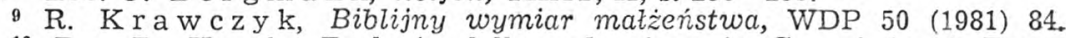

10 Por. R. K o ch, Teologia della redenzione in Genesi 1-11, Roma 1967, s. 76-79; M. Filipiak, Biblijne podstawy teologii matżeństwa, ŻM 30 (1980), nr 3, s. $12-22$.

11 Por. M. A dinolfi, dz. cyt., s. $54-58$. 
była na grzech bardziej podatna ${ }^{12}$. Z owej kolejności nie można wyprowadzać żadnych wniosków, ponieważ opis ma charakter sztuczny - kolejność grzechu, przesłuchania i wygłoszenia wyroku wynika z kompozycji literackiej Rdz 3. Opowiadanie Rdz 3 ma zresztą charakter wybitnie symboliczny. Pokusa oraz grzech zaczęly się od kobiety, ponieważ jahwista chciał podkreślić uniwersalność popełnionego zła, które przeszło na wszystkich ludzi poprzez ,matkę wszystkich żyjących" ( $\mathrm{Rdz} 3,20)$. Wyrok Boży dla kobiety: „W bólu będziesz rodziła dzieci, ku twemu mężowi będziesz lgnęła, on zaś będzie panował nad tobą" ( $R d z ~ 3,16)$ - dosięga samego rdzenia jej istoty, jej powołania jako matki. Przy wyjaśnianiu tych słów trzeba uwzględnić w pierwszym rzędzie codzienne ludzkie doświadczenie. Mimo szczęścia, jakie daje macierzyństwo, musi kobieta znosić w okresie ciąży wiele dolegliwości i wśród cierpień rodzić nowe życie. To jest jeden ciężar ją przygniatający. A drugi - przynajmniej tak się działo w bliższym i dalszym otoczeniu autora biblijnego na całym Wschodzie ${ }^{13}$ - to panowanie nad nią mężczyzny i poniżające jej godność osobistą stanowisko. Wszystkie jej pragnienia kierują się ku mężczyźnie. Chce jego opieki, oczekuje od niego bezpieczeństwa i obrony, marzy o wyzwoleniu i niezależnym uzupełnianiu go, pragnie uznania i zjednoczenia z nim duchowego i cielesnego. Lecz jak okrutne w rzeczywistości spotyka ją rozczarowanie! Mężczyzna nie traktuje kobiety jako równouprawnionej z nim partnerki, lecz jak poddaną, jak niewolnicę. Tego rodzaju stosunek nie jest zgodny z wolą Bożą, lecz stanowi następstwo upadku i załamania się samego człowieka. W wyroku Bożym można więc dostrzec, jak podkreśla W. Trilling ${ }^{14}$, obok cierpień macierzyństwa, panowanie nad nią mężczyzny. Innymi słowy $R d z$ 3, 16 nie wprowadza dominacji mężczyzny nad kobietą, ani też nie ustanawia żadnego osłuszeństwa żony względem męża: zdanie to - w duchu wyjaśnienia etiologicznego ${ }^{15}$ - tłumaczy jedynie faktyczny stan sytuacji kobiety: w praktyce była ona podporządkowana mężczyźnie.

W sposób szczególny autor biblijny podkreśla funkcję i godność kobiety jako matki. Wyraża to imię Ewa - „matka wszystkich żyjących (hebr. 'ém kol - haj ${ }^{16} ; \mathrm{Rdz} 3,20$ )". Nadając to imię, jahwista

12 To ostatnie sugeruje M. Peter, Wyktad Pisma św. Starego Testamentu, Poznań 1978, wyd. 3A, s. 219.

13 Por. J. Seibert, Die Frau im Alten Orient, Leipzig 1973, s. 12-30; Por taki̇e, H. L o e w e, The Position of Women in Judaism, London 1966.

I: Stworzenie $i$ upadek wedtug Rdz 1-3, Warszawa 1980, s. 99.

15 Zob. N. Lohfink, Genesis 2 f. als ,geschichtliche Äitiologie". Gedanken zu einem neuem hermeneutischen Begriff, "Scholastik” 38 (1963) $321-334$.

${ }_{16}$ Wyrażenie 'ēm - haj wystẹpuje w Syr 40,1 (hebr) w odniesieniu ziemi. Ziemia jest matką wszystkich żyjących. Natomiast tekst grecki Syr ma: meter pántōn - „matka wszystkich". A. Bonora (La creazione: il respiro della vita e la madre dei viventi in Gn 2-3, w: Parola spirito 
kładzie akcent na apoteozę macierzyństwa, tak charakterystyczną dla ST. W ten sposób Rdz 2-3 podkreśla, że kobieta wraz z mężczyzną, razem stanowią koronę całego stworzenia ${ }^{17}$.

\section{WYPOWIEDZI O KOBIECIE W MYŚLI SAPIENCJALNEJ ST}

Autorzy nurtu mądrościowgeo ST wiele miejsca poświęcają kobiecie ${ }^{18}$. Poemat o dzielnej niewieście (Prz 31, 10-31) ${ }^{19}$ będący pouczeniem o idealnej żonie, sugeruje czytelnikowi, że związek pomiędzy kobietą i mężczyzną winien opierać się na dialogu i zaufaniu oraz uznaniu kobiety jako pełnoprawnego partnera. Kobieta ma prawo do podejmowania samodzielnych decyzji: („Pragnie zakupić pole i nabywa je”, w. 16; „Płótna lniane tka i sprzedaje, kupcowi poleca wspaniałe pasy", w. 24), docenia się jej rolę, jako roztropnego doradcy („Usta otwiera z rozwagą", w. 26). Niewiasta przedstawiona w tym poemacie nie jest bynajmniej niewolnicą przy boku swego męża i pana, ale osobą niezależną i odpowiedzialną w podejmowanych decyzjach. Zgodnie $\mathrm{z} \mathrm{Rdz} 2,18$ odgrywa rolę równorzędnego towarzysza swego męża ${ }^{20}$. Dlatego Prz $5,18-20^{21}$ apeluje o dochowanie wierności małżonce: „Raduj się żoną twojej młodości! Łania to najmilsza! Kozica pełna wdzięku! ... Dlaczego synu mój, miałbyś się odurzać u boku cudzej niewiasty i obejmować łono nieznanej?" (por. $\operatorname{Prz}$ 5, 15; Koh 9, 9). Kohelet będąc pod wplywem Rdz 2--32.2, powie, że kobieta może spelniać taką samą rolę, jak mężczyzna, gdyż jest ona takim samym człowiekiern. Po odrzuceniu tradycyjnych opinii o kobiecie (Koh 7, 26. 28), Kohelet stwierdza: „Bóg uczynił ludzi (jednakowo) prawymi, lecz oni szukają rozlicznych wybiegów" (7, 29), tzn. kobietę i mężczyznę obdarzył takimi samymi właściwościami.

e vita (t. 5), Bologna 1982, s. 21) uważa, że Syrach używa tutaj języka mitologicznego po to), aby w ten sposób wyrazić ideę, iż człowiek jako „,istota z ziemi” po śmierci wraca do ziemi - matki. Zob. także G. L. P r ato, Il problema della teodicea in Ben Sira, Roma 1975, s. 302. 315-317.

17 Por. J. A. B a iley, Initiation and the Primal Woman in Gilgamesh and Genesis 2-3, JBL 89 (1970) 137-150.

18 Por. S. Amsler, La sagesse de la femme, w: La Sagesse de l'Ancien Testament (par. M. Gilbert), Leuven 1979, s. 112-116; P. H u mbert, La ,femme étrangère du Livre des Proverbes, Rev ES 6 (1937) $49-64$.

19 Zob. M. B. Crook, The marriageable maiden of Prov. 31, 10-31, JNES 13 (1954) 137-140.

20 Por. komentarz BP do Prz 31, 10-31.

21 Por. A. De Nicola, „La moglie della tua giovinezza" (Prov. 5, 15-19), Bibor 12 (1970) 153-183.

$22 \mathrm{Na}$ antropologiczne poglądy Koheleta wielki wpływ wywarł opis stworzenia świata w Rdz; por. M. Filipiak, Kohelet a Księga Rodzaju, RBL 2-3 (1973) 78-85; Ch. C. Forman, Koheleth's Use of Genesis, JSS 5 (1960) 256-263. 
Opinie krzywdzące (pod adresem kobiety) - to "wybiegi”, „pomysły” ludzi (tzn. mężczyzn, jak to sugeruje zaimek męski hèmmāh, „oni”) ${ }^{23}$. Temat kobiety pojawia się w szczególnie bogatej postaci, jaką reprezentuje autor Pnp ${ }^{24}$. Utwór ten pierwotnie opiewał szlachetną miłość ludzką rozumioną w duchu teologii jahwisty i innych ksiąg mądrościowych ${ }^{25}$. Punktem wyjścia dla autora Pnp była pierwsza biblijna pieśń miłosna ( $\operatorname{Rdz} 2,15-24)$. To było jej pierwotne Sitz im Leben. Każdemu czytającemu tę księgę narzuca się nieodparcie jej ścisły związek z tekstami ST, które mówią o ustanowieniu małżeństwa (Rdz 2, 15-24), o miłości i wierności małżeńskiej (Rdz 24,67; Ma 2, 14). Pnp kontynuuje naukę tych tekstów o naturalnej ludzkiej miłości jako rzeczy świętej, przez Boga ustanowionej i nakazanej człowiekowi. Dopiero to głębokie przeświadczenie o miłości jako rzeczy dozwolonej, a nawet świętej sprawiło, że późniejszy redaktor nawiązując do prorockiej alegorii małżeńskiej (drugi Sitz im Leben) mógł księgę przepracować nadając jej sens alegoryczny (pieśń o miłości Jahwe-Oblubieńca i Izraela Oblubienicy) ${ }^{26}$.

Istotny wkład Pnp to podkreślenie partnerstwa w sferze miłości. W tekstach traktujących o pożyciu małżeńskim miało się dotąd na względzie jedynie satysfakcję mężczyzny, nie uwzględniając zupełnie doznań kobiety. W tym względzie oblubieniec i oblubienica w Pnp są równorzędnymi partnerami. Ponadto Pnp rozwija myśl, że stosunki małżeńskie obok ich wartości jako środka (prokreacja), mają jeszcze swą własną wartość; przynoszą kobiecie i mężczyźnie osobistą satysfakcję i umożliwiają psychiczny rozwój.

A co na temat kobiety mówi Syrach? Trzeba przyznać, że Syrach temu zagadnieniu poświęca dość dużo miejsca w swojej księdze (Syr $25,13-26,27 ; 36,21-27)$. Oceniając stanowisko, jakie zajmuje Syrach $^{27}$ względem kobiety, należy pamiętać, iż $w$ tej kwestii jest on calkowicie zgodny z poglądem ST, który z jednej strony podkreślał wielką godność kobiety ${ }^{28}$, widząc w niej ,pomoc" stworzoną dla s. 157.

23 Zob. M. Filipiak, Księga Koheleta (PST VIII-2), Poznań 1930,

24 Zob. P. Grelot, Le sens du Cantique des Cantiques, RB 71 (1964) 42-56; H. Gollwitzer, Il poema biblico dell'amore tra womo e donna. Il Cantico dei Cantici, Torino 1979.

25 A. M. D ubarle, L'amour humain dans le Cantique des Cantiques, RB 61 (1954) 67--86; M. Adinolfi, Il feiminismo della Biobia, s. $74-96$.

26 Por. M. Filipiak, Biblijne podstawy teologii matżeŕstwa, ŻM $30(198 j)$, nr 3, s. 21, odnośnik 24.

27 Por. M. Gilbert, Ben Sira et la femme, RTL 7 (1976) 426-442; zob. także: H. IM c K e ating, Jesus ben Sira's Attiude to Women, ExT 85 (1973-74) 85-87.

z3 Zob. np. A. B onora, Riflessioni bibliche sulla liberazione e promozione della donna, „Humanitas” 32 (1977) 630-649; F. Mo n ta g n in i, La donna nella legge mosaica, "Parole di vita" 20 (1975) 405-418; $\mathrm{H}$. $\mathrm{L}$ o e w e, The Position of Women in Judaism, London 1966. 
mężczyzny (por. $R d z$ 2, 18), z drugiej zaś strony jest odbiciem wpływów bliskowschodniego kręgu kulturowego, wyrażający się w dyskryminacji i rygorystycznym jej traktowaniu (por. $\mathrm{Rdz} 3,16$ ). Wiele miejsca poświęca Syrach wadom kobiecym. Przedstawia w sposób niezmiernie wyrazisty złośliwość kobiecą: „wszelka złość, byle nie złość kobiety" (25, 13b), prawdopodobnie mając na uwadze wrogość żony, której mąż nie darzy należytymi względami. W różny sposób wyraża Syrach swój negatywny sąd o kobiecie. Najpierw ukazuje kłopoty, jakie ona niesie dla życia rodzinnego. „Udręką serca i bólem jest kobieta zazdrosna o druga kobietę, wszystko to jest biczem języka” (Syr 26, 6). „Bicz języka” wyraża tu plotki i oszczerstwa wynikające $z$ zazdrości i rywalizacji żon o prerogatywy w sprawach małżeńskich i rodzinnych. To samo ma autor na myśli radząc: „(Nie naradzaj się) z żoną co do jej rywalki" (Syr 37, 11). Teksty te świadczą, że autor stykał się na co dzień z bigamią i problemami, jakie $\mathrm{z}$ tym są związane.

Kreśląc obraz wad kobiecych Syrach przypomina, że „początek grzechu przez kobietę i przez nią też wszyscy umieramy" (Syr 25, $24)^{29}$. Nawiązując bezpośrednio do $\operatorname{Rdz} 3$, autor obarcza kobietę odpowiedzialnością za zaistnienie grzechu i śmierci na świecie ${ }^{30}$. Wydaje się jednak, że w wypowiedzi Syracha nie można dopatrywać się poglądu, iż kobieta ma większy udział w grzechu, a przez to jest bardziej odpowiedzialna, tylko należy tę wypowiedź rozumieć $\mathrm{w}$ tym sensie, że zgodnie $\mathrm{z}$ relacją $\mathrm{Rdz} 3$ kobieta jest chronologicznie pierwszą przy podejmowaniu decyzji ${ }^{31}$.

Jak oceniać postawę Syracha wobec kobiety? Być może, iż Mędrzec w ten sposób szuka uzasadnienia faktycznej sytuacji kobiety: zajmuje ona podrzędną pozycję ze względu na swoje przyrodzone wady ${ }^{82}$. Prawdopodobne jest również tłumaczenie złych ocen kobiet racjami typu psychologicznego. Zważmy, że biblijne ,portrety” kobiet są dziełem mężczyzn. Ich surowość w ocenie kobiet stanowi swoisty odwet za to, że tylu więzami mężczyźni są uzależnieni od „płci słabej”. Najbardziej jednak przekonywujące wydaje się był tłumaczenie: biblijne „katalogi" wad kobiecych zawarte są przede wszystkim w biblijnej literaturze przysłowiowej ${ }^{33}$. Ponieważ są to najczęściej przy-

29 Szerzej na ten temat zob.: T. G a $11 \mathrm{us}$, „A muliere initium peccati et per illam omnes morimur" (Sir 25, 24 (33), VD 23 (1943) 272-277.

30 Taki pogląd reprezentują: A. Miniss a le, Siracide, Roma 1980, s. 133, G. Snaith, Ecclesiasticus, Cambridge 1974, s. 130, A. Eber-harter, Das Buch Jesus Sirach oder Ecclesiasticus, Bonn 1925, s. 94 i inni.

81 Takie stanowisko reprezentuje M. Filipiak (Biblijne podstawy teologii małżénstwa, s. 13); M. A. D u barle (Les Sages d'Israël, Paris 1946, s. 174-175).

82 Por. E. B. J e gie r, art. cyt., s. 99.

33 Por. E. G. Ba uckmann, Die Proverbien und die Sprüche des Jesus Sirach, ZAW 72 (1960) 33-63. 
słowia, wyrażają dostrzegalne w codziennym życiu przywary kobiet, a nie orędzie ST o naturze godności i powołaniu kobiety. Księga Syracha zawiera różne obrazy kobiet, obrazy pozytywne i negatywne, zawsze jednak $u$ ich podstaw leży pewna myśl wspólna oscylująca wokół idealnego wzorca kobiety; zawsze odróżnia się kim ta lub inna kobieta jest, a kim może i powinna być.

Po przestrogach przed skutkami złośliwości kobiecej przechodzi Syrach do opisu cech pozytywnych, jakie w życie rodzinne wnosi kobieta (Syr 26, 1-16). Uwagi te świadczą, że Mędrzec nie jest wrogiem kobiet, co mogłoby sugerować poprzednie wypowiedzi. W sposób jednoznaczny stwierdza, że ,kto zdobędzie żonę, ma początek pomyślności, pomoc podobną do siebie i słup oparcia" (Syr $36,24)$. Wypowiedź ta nawiązuje do $R d z$ 2, $18 \mathrm{w}$ sposób zasadniczy. Przemawia za tym użyty $w$ tekście hebrajskim Syr termin ezer (pomoc). W ten sposób autor podkreśla również godność kobiety. Aby nie było żadnej wątpliwości, wzmacnia swoją argumentację słowami: „słup oparcia”, podkreślając, iż kobieta w porządku egzystencjalnym stanowi dopełnienie mężczyzny. Dlatego Syrach przestrzega przed nierozważnymi rozwodami, których był świadkiem. „Masz żonę według twego upodobania, nie odrzucaj jej” (Syr 7, 26a). „Nie odchodź od żony mądrej i dobrej, albowiem miłość jej ponad złoto" (Syr 7, 19). Nawet najcenniejsze skarby nie posiadają tej wartości, co dobra żona (por. Syr 26, 1-4. 13-18. 26; 36, 24-25) dlatego opuszczenie jej jest znakiem głupoty.

Warto zauważyć, że w cytowanych wyżej tekstach na temat kobiety $w$ Księdze Syracha, autor ma zawsze na względzie dobro mężczyzny. Swiadczy to, że w czasach Syracha kobieta była wciąż jeszcze człowiekiem drugiej kategorii. Chociaż Syr nawiązuje do wizji małżeństwa zawartej $\mathrm{w} R \mathrm{dz} 2$, to jednak jest pod wpływem obecnej sytuacji, jaka w jego czasach istniała.

Reasumując, należy stwierdzić, iż księgi mądrościowe ST nawiązując do $\mathrm{Rdz} 1-3$, przedstawiają kobietę, która ma swoje dobre i złe cechy charakteru, ale $\mathrm{w}$ porządku godności jest równa mężczyźnie; tak samo jak on jest stworzona na obraz Boży. To giębokie teologiczne spojrzenie mędrców izraelskich na kobietę - obraz Boży, przyczyni się do zmiany stanowiska, jakie wobec kobiety zajmie Jezus Chrystus ${ }^{84}$.

Siedlce

KS. ROMAN KRAWCZYK

34 Szerzej na ten temat zob. C. Buzetti, Gesù e le donne, „Parole di vita" 20 (1975) 433-450; E. F. Stagg, Woman in the World of Jesus, Philadelphia 1978; M. A dinolfi, Il femminisimo della Bibbia, s. $118-144$. 